\title{
The Impact of a Global Crisis on the Economic Sustainability of Nigeria: The Case of Covid-19 Pandemic
}

\author{
AJAYI Ibidolapo Ezekiel ${ }^{1}$, EDEWUSI Damilola Gabriel ${ }^{2}$ and ADELEKE Kareem Olalekan ${ }^{3}$ \\ 1,2 Department of Finance, Ekiti State University, Ado-Ekiti, Ekiti State, Nigeria \\ ${ }^{3}$ Department of Banking and Finance, Federal Polythenic, Ado-Ekiti, Nigeria
}

\begin{abstract}
This study assessed the impact of a global crisis on the economic sustainability of Nigeria. The present study explored the effect of the exchange rate, oil price, and investment rate on the financial sustainability of Nigeria. It adopted the qualitative and quantitative research design in its approach. The study gathered quarterly time series data spanning from 2016 Q1 to 2020 Q2. Econometrics estimations, including ARDLcointegration analysis, parsimonious error correction model, and other post estimation tests, were used to analyze the study data. Findings from the study revealed that in the long run, exchange rate, oil price, and investment rate exert a positive impact on economic sustainability, and in the short run, exchange rate and oil price exert s negative impact on financial sustainability, while investment rate impact positively on economic sustainability. Following these findings, the study suggested that the Central Bank of Nigeria should maintain the stability of the exchange rate. The Government of Nigeria should switch the economy from a single or mono-economy, and the Central Bank of Nigeria should further improve financial inclusion.
\end{abstract}

Keywords: Global crisis, Economic sustainability, COVID-19, Exchange rate, Oil price, Investment rate

\section{INTRODUCTION}

$\mathrm{T}$ his paper is not just coming at an appropriate time, but it is also vital considering the gravity of the anomaly faced by the global economy at a time like this.COVID-19, or the coronavirus is a new disease that has posed severe economic pressure to nations of the world; it was discovered in 2019 with no recent observation of the disease in humans (Wang \& Zhou, 2020). The COVID-19 pandemic has continued to inflict suffering, especially with the consistent increase in macroeconomic variables, and most, unfortunately, the decline in oil price and investment has caused nations to strive to control the virus and equally sustain the prosperity that they used to possess (Adeyinka, Fadila, Bodam, Dansofo\&Adetunji, 2020). It has been observed that economic crisis is usually occasioned by consistent market decline, market failure, price shocks, political instability, and civil disorder (Jones, 2016; Hart \& Tindall, 2009; Francois \& Woerz, 2009; Petrakos, 2014; Lagravinese, 2015; Giugni \& Grasso, 2016; Bernburg, 2016).

Although economic crises or recessions are almost expected in Nigeria (Ozili, 2020), following her previous experiences, in 2016, the recession caused the Central Bank of Nigeria to ensure the local currency did not devalue against the dollar with the adoption of a controlled float foreign exchange system, which was effectively used through 2016 to 2019. The corollary of the 2016 recession instilled in Nigerians the belief that the unfortunate and shocking continuous fall in oil prices resulted from the economic downturn in Nigeria. However, in 2020, the global crisis caused by a pandemic caught nations by surprise. The reason for the contrast between the COVID19 pandemic and the economic situation in Nigeria was because the financial advisors whose input would have restored the economy were constrained from carrying out economic activities, especially with the lockdown strategy used by the government towards containing the spread of the coronavirus disease (Ozili, 2020).

The Nigerian economy has over the years reflected a high level of weakness and vulnerability to global economic issues, and this is most certainly caused by its overdependence on the oil sector and related foreign exchange income leveraged upon by the government to enhance the growth and development of the country (Nwugbe \& Ogbuagu, 2014). As a result of the global crisis caused by COVID-19, countries such as Nigeria, whose oil and gas sector has, over time, experienced a massive price increase. Consequently, they sustained their economic growth are faced with severe financial torture. According to the Nigeria Minister of Finance, the oil price shock has imposed noticeable pressure on the nation's budget and the value of its currency, thereby occasioning several bids by the government to cut and modify the 2020 budget to suit the current economic situation. Similarly, the Accountant-General of the Federation maintained that the current balance of Nigeria's Excess Crude Account stood at US\$71.81 million, although the country's reserve fell by US $\$ 2.16$ billion from the US $\$ 38.53$ billion, which was the opening balance for the year (Rabiu, Musa, Isah \& Adamu, 2020).

However, it is noteworthy that the price of a barrel of crude oil, according to the Finance Minister, stood at \$57, which the president had previously approved before the arrival of COVID-19 crashed it to the recently modified price of US $\$ 25$ per barrel despite slashing the estimated crude oil production 
capacity from 2.18 million barrels per day to 1.94 million barrel per day (Rabiu et al., 2020). The spillover from COVID-19 was also evident in the financial sector as borrowers' capacity to observe their obligation was negatively impacted, hence heightening non-performing loans, triggering unimpressive earnings, and the instability of firms in the financial market sector (Ozili, 2020).

The economic downturn that came as a result of corvid-19 was utterly unbearable. Measures were put in place by nations and international financial institutions to curtail further economic misfortune. Despite these efforts, the future of the global economy remains bleak as developing countries like Nigeria exert effort to sustain economic activities and maintain a healthy economy after the pandemic (Adeyinkaet al., 2020). Before the pandemic, Nigeria's GDP growth rate was put at 2.3 percent. Still, in the first quarter of 2020, its GDP only grew by 1.87 percent, thereby necessitating the need to borrow, which led to a further increase in its debt profile. The global crisis triggered a massive fall in the value of stock prices of corporate firms, hence deteriorating investors' wealth and deflating the interest of potential investors as they are uncertain of a future after the pandemic. Also, the recent hike in the exchange rate caused the government of Nigeria to float its currency, thereby introducing a policy that reflects currency overvaluation (Adeyinka et al., 2020).

This deliberate act, without doubt, saw the increase in Nigeria's exchange rate as its government had wrongly accepted the idea of sustaining economic growth and development by floating its currency. The action triggered a distortion in the economy of Nigeria as envisaged by Killick (1992) in the hike in prices of local products and its negative impact on the nation's balance of trade and dwindling economic growth. Furthermore, the pressure exerted by the pandemic on the economies of the world brought significant studies in respect of the effect of COVID-19 and the sustainability of the world's economy. However, the researchers observed that few pieces of research have been conducted on this area of focus and that they employed qualitative research design (Adeyinka et al., 2020; Ozili, 2020; Rabiu, Musa, Isah \& Adamu, 2020; Ahmad, Haroon, Baig \& Hiu, 2020; Joshi, Bhaskar \& Gupta, 2020; Ozili \& Arun, 2020). Hence, this study will adopt both qualitative and quantitative research design in its approach and will amass data that will span across periods that were significantly affected by the pandemic to reach a realistic conclusion. This study will mainly gather quarterly data of proxies selected towards adequately tracking both the short-run and long-run effects of the pandemic on the sustainability of Nigeria's economy using the Parsimonious Error Correction Model and Johansen Co-integration estimation techniques. Also, this study will assess the effect of the exchange rate, oil price, and investment rate on the economic sustainability of Nigeria.

\section{LITERATURE REVIEW}

\subsection{Coronavirus(COVID-19)}

COVID-19 is an infectious disease occasioned by the recent pressure of coronavirus. The acronym COVID-19 represents coronavirus disease, while 19 stands for the year the outbreak was noticed; the condition was in the past known as 2019nCoV or 2019 novel coronavirus. The recently discovered virus is associated with the same group of viruses as Severe Acute Respiratory Syndrome (SARS) and some forms of usual cold (WHO, 2020). Numerous appearing and disappearing viral infections have befallen several countries at different periods leaving the affected economies in utter economic downturns (Akpoveta \& Edheku, 2020); these diseases could either be benign or malignant with changing clinical appearance.

Reports from the Chinese Centre for Disease Control and Prevention and the World Health Organisation demonstrate that the emergence of the severe acute respiratory syndrome (SARS), the Middle East respiratory syndrome (MERS) in 2002 and 2003, and another outbreak experienced in 2012, exposed the world to diseases that never spared the economy of many nations (Akpoveta \& Edheku, 2020). Rahman and Bahar (2020) stated that almost immediately after the challenges of pneumonia in Wuhan, China, the world became exposed to the coronavirus resulting in coronavirus disease, mostly known as COVID-19. The first group of pneumonia cases reported to the WHO on 31 December 2019 was still being assessed when COVID-19 appeared, triggering a global health disaster on 30 January 2020.

Coronavirus or COVID-19 relates to a group of viruses that may occasion numerous signs such as fever, pneumonia, lung infection, and difficulty in breathing. These diseases are easily noticeable in animals. However, little or no cases were noticed amongst humans until a group of patients with medical issues associated with pneumonia was discovered in December 2019 in a local seafood market in Wuhan, Hubei Province, China. In reaction to finding the strange disease, the Chinese Centre for Disease Control and Preventionkick-started an epidemiological and etiological investigative approach with health authorities and other medical teams in Wuhan (Chinese CDC, 2020). The WHO ascertained that the emergence of the coronavirus pandemic was connected to the Huanan South China seafood marketplace and that no particular person was identified to be associated with the disease (Akpoveta \& Edheku, 2020).

Scientists initiated research to trace the origin of the novel coronavirus. The newly discovered genome of COVID-19 was printed on 10 January 2010 by the research group spearheaded by Prof. Yong-Zhen Zhang. In the space of one month, the said virus had spread to other parts of China because the outbreak occurred during the Chinese New Year, a time when a large number of people gather for activities. The virus, transmitted through droplets, contacts, and aerosol transmission, caused the infection of persons of diverse 
nationalities and races. The exit of infected persons from the country consequently occasioned the exportation and spread of the virus across several countries of the world. While the global community makes attempts to fight the pandemic, nations of the world are faced. They will be challenged with strange economic actualities, which might range from slight to critical according to the financial position of the country before COVID-19 (Akpoveta \& Edheku, 2020).

\subsubsection{Global Economic Implication of the COVID-19 Pandemic}

The COVID-19 came from China, a country with the largest population of almost 1.4 billion people and the second-largest economy in the world with a gross domestic product of about 13.6 billion USD (WHO, 2020; Lee \& McKibben, 2004). China has been grappling with the COVID-19 pandemic since December 2019, but the attack deteriorated and grossly affected the economy of China in the quarter of 2020. China is unarguably a significant country as it represents the primary source of demand and supply of numerous products. It is also a country of interest for financial markets and nations; hence adverse developments in China exert negative influences on other countries (OECD, 2020). According to the Organisation for Economic Cooperation and Development (OECD), the possibility of growth for China at a point fell by $5 \%$ in the first quarter of 2020 after the initial reduction of about $6.1 \%$ experienced in 2019. Expectedly, the global economic growth would drop and maintain about $2.4 \%$ in 2020 , relative to the initial position of $2.9 \%$ in 2019 . However, the decline could drag the global economic growth to $1.5 \%$, considering drastic fall in the general international economic activities (OECD, 2020)

In 2018, China took the lead in exporting goods and services with a cumulative export worth $\$ 2.7$ trillion and import worth \$2.6 trillion (Jones, 2018). Following this record, its production association with other nations spread over a vast space that cannot be surpassed. China maintains a significant role in global supply chains as a manufacturer of industrial goods, especially in transportation, machinery, computers, pharmaceuticals, electronics, and the primary source of demand in the production of raw materials (Acikgoz \& Gunay, 2020). According to the General Administration of Customs, China's general exports and imports shortened by $17.2 \%$ and $4 \%$ accordingly in the first two months of 2020 (Customs Report, 2020). During that period, its industrial production activity reduced by $13.5 \%$, and industrial return fell by $38.3 \%$. All over the world, businesses grappled with reducing revenue and unstable supply chains, a spillover of the total closure of factories in China in their quest to curtail the spread of COVID-19. Acikgoz and Gunay(2020) noted that the government of China's decision to extend factory closure adversely impacted the supply of numerous products and affected the ability of multiple markets to produce goods.

Meanwhile, before the escalation of COVID-19, one of the biggest investment banks in Europe referred to as Societe
Generale, announced that its clients should desist from investing in Nigerian government debt security, mentioning that the security might be challenged with a high and unachievable exchange rate (Akpoveta \& Edheku, 2020).

In addition, a massive fall in oil demand followed the global economy's shut down. According to the agency, the International Energy Agency reports that the world should envisage a reduction in oil demand; this, according to the agency, would mark the first after the financial crisis experienced in 2009. Despite this, the agency further asserted that an increased supply of oil should also be expected due to the failure of Russia to reduce oil production as agreed between the country and Saudi Arabia. Premium Times revealed that for three years, during the Saudi-led administration, OPEC has proffered utter support towards increasing oil prices by reducing production with its counterparts, including Russia, Mexico, and others. The administration attained its goals as oil prices jumped from $\$ 26$ in January 2016 to about $\$ 85$ in October 2018. However, the recent OPEC+ cabal led by Russia rejected Saudi Arabia's appeal to reduce production. In reaction to the adamant response of the Russian-led administration, Saudi Arabia destroyed the agreement with OPEC and vowed to establish its oil pumps (Premium Times, 2020).

The demand-supply imbalance stemming from the disagreement between the OPEC+ cabals significantly affected Nigeria, hence the country's struggle to sell its oil. Currently, Nigeria's crude oil products are being exchanged for a discounted price, a situation that was not experienced during the 2009 financial crisis (Akpoveta \& Edheku, 2020). This suggests that the disagreement between the two OPEC cabals also contributed to the plunge in oil prices aside from the influence of the COVID-19 pandemic. The economy of Nigeria is grossly affected by the rapid fall in oil prices through relatively low government finance and price actions. Foreign exchange has also been negatively and significantly affected. However, for oil prices to return to their normal profitable state, Nigeria would require a rapid and responsive solution to the COVID-19 pandemic. Akpoveta and Edheku also remarked that significant oil producers should be made to consent to reduce oil production.

The collapse of the oil market brought terrible news for the exchange rate as a limited amount of dollars was noticed in the nation's economy, especially after the massive drop in investment rate occasioned by the global recession. The evidence became clear that the naira would experience a callous time as the OPEC+ cabals failed to reach a reasonable consensus, thereby causing the crash of oil prices. Due to the reduced foreign exchange and the low flow of dollars into the economy, the Central Bank of Nigeria, in the bid to attract potential foreign deals, modified the official rate of one dollar from N305 to N360; the apex bank also shot up the amount at which it exchanged currency to foreigners by about $4 \%$ (Reuters, 2020). According to Akpoveta and Edheku, the naira has recently been traded for a meager amount in the primary 
flexible foreign exchange market; that is, the investors' and exporters' market, and the situation is expected to worsen as the pandemic eats deep into the economy of the country.

\subsubsection{Economic Implication OF COVID-19 Pandemic in Nigeria}

Nigeria had employed several measures towards preventing coronavirus from the country; however, despite the efforts of the Nigerian government, the country confirmed its first confirmed case on 27 February 2020, and afterward, the number of infected persons in the country have proliferated daily almost beyond control (Akpoveta \& Edheku, 2020). Like other economies leveraging significantly on oil revenue, Nigeria is faced with critically uncertain times as it grapples with double economic shock, including COVID-19 pandemic, global and domestic crisis, and oil price shock. According to Akpoveta and Edheku, the cause of the gross effect of the highlighted external economic issues could be associated with its heightened dependence on global economies for fiscal income, funding of budgetary deficits, foreign exchange inflows, and capital inflows necessary for the sustainability of the nation's economy. As the world makes an all-out effort to control the dominance of the virus, the spread and casualties caused have been on the increase; as of writing, the total number of confirmed cases in the world stands at 11,376,000 and 532,035 deaths, with Nigeria specifically recording 28,167 confirmed cases and 634 deaths.

Nigeria is currently in a tight corner as it initially dealt with the chance of experiencing a continuously reduced oil price before the pandemic, which obstructed the interactional relations of the externally reliant country (Akpoveta \& Edheku, 2020). However, the multiplying coronavirus cases in the government signaled the need for a partial or incomplete shutdown of the country, which exposed the Nigerian economy to structural damage occasioned by faulty policies. Despite the unclear health chances maintained by Nigeria as the virus spreads almost without control, it is without a doubt that the economic implication of the virus will be critical and almost changeless for Nigeria. According to the Central Bank of Nigeria, the Manufacturing Purchasing Managers Index within the first quarter of 2020 dropped from 58.3 to 51.1, the lowest value recorded since 2017. Also, non-manufacturing PMI such as agriculture and services reduced below 50, setting a new and strange record since 2017. Sadly, the jobs of the few employed in Nigeria are seriously at stake as firms across the manufacturing and service sectors are underperforming (CBN, 2020).

Following the shutdown of the global economy, investment in Nigeria has been on the decline as foreigners prefer to pursue stakes in more secured assets such as US government bonds. Reports from the Institute of Internal Finance indicate that foreign investors withdrew investment worth over $\$ 80$ billion out of several corporations in Nigeria in February and March. Again, an American-based credit rating agency recently reduced Nigeria's government debt credit rating to B-. It is expected that this report would deter investors' interest in the county. Similarly, Fitch Global Rating Hong Kong also reports that Nigeria's Long Term Foreign Currency Issuer Default Rating (IDR) has reduced from B+ to B. Nigeria has further attracted for itself flow investment potentials with the recent attempt by the CBN to dispose of its particular OMO securities to foreign investors.

\subsection{Theoretical Underpinning}

This study is hinged on the supply-leading and demandfollowing hypothesis. The supply hypothesis was postulated by Schumpeter in 1911 when the author posited that financial deepening and inclusion improves economic growth. Thus, the availability and improvement of financial markets heighten savings and investment and ultimately enhance the efficacy of capital accumulation, which directs economic growth (Ozigbu, 2018). Furthermore, the supply leading hypothesis is based on the idea that the effectuality of financial institutions commands efficiency in the economy, occasions and improves liquidity, causes proper mobilization of savings, improves capital accumulation, and directs economic resources from non-performing sectors to sectors with potentials for growth (Ohwofasa \& Aiyedogbon, 2013). Adeyeye, Fapetu, Aluko, and Migiro (2015) averred that financial deepening triggers economic prosperity. Based on this premise, the development of the financial sector is considered an antecedent for the fair sharing of financial resources. In general, the supply-leading hypothesis points that the increase experienced in the actual industry is a function of the height of financial development noticed in the country; therefore, expectedly, financial deepening will occasion massive prospects and finally ascertain economic sustainability.

Again, this study is anchored on the demand-following hypothesis. Robinson suggested the demand-following hypothesis in 1952 . The theory is premised on the idea that financial deepening is well associated and controlled by the level of growth experienced in the economy. The proponent of the hypothesis identified that part of the benefits of sustainable economic growth is the improved demand for financial services, which eventually drives development in the financial sector. Put differently, sustainable economic growth enhances the need for money, which promotes financial services and, by implication, enhances the prosperity of the financial industry (Karimo\& Oliver, 2017). Hence, the development and progress of financial markets is a function of the increasing demand for goods and services provided by the real sector. The growth of the real sector and macroeconomic indicators encourages development in the financial industry (Robinson, 1952). Proponents of monetary economics affirmed that the demand-following idea of growth in the financial markets ordinarily responds to growth in the economic position of the country as growth noticed in the real sector provokes increasing opt-ins for financial services and products. 


\section{METHODOLOGY}

This study modified the model employed byNgwube and Ogbuagu (2014) to examine the global financial crisis and the Nigerian economy. The researchers in this study captured Nigeria's financial market with all share indexes. In contrast, the effect of the global financial crisis was captured with market capitalization, oil price, exchange rate, inflation rate, unemployment rate, and gross domestic product. For simplicity, the functional form of the modified model is reflected below:

$G D P=f(E X R, O I L P, I N V R)$

Where GDP is presented as the dependent variable, which is a measure of the ability of the nation to sustain its economic growth and exchange rate, oil price, and investment rate (proxied with total savings) are other financial proxies, the model is specified in its linear form below:

Linear representation of the models:

$\mathrm{GDP}=\mathrm{B} 0+\mathrm{B} 1 \mathrm{EXR}+\mathrm{B} 2 \mathrm{OILP}+\mathrm{B} 3 \mathrm{INVR}$

$\mathrm{GDP}=\mathrm{B} 0+\mathrm{B} 1 \mathrm{EXR}+\mathrm{B} 2 \mathrm{OILP}+\mathrm{B} 3 \mathrm{INVR}+\mu$

Source(s) of Data and Estimation Techniques

This study sampled quarterly data in Nigeria spanning from 2016-2020 (second quarter). The study mainly amassed data from 2016 because Nigeria experienced an economic shock similar to the current experience in 2019 towards 2020. Data were gathered from the compilations of the Central Bank of Nigeria and the Nigeria Bureau of Statistics. The study employed correlation tests, unit root tests, co-integration tests, parsimonious error correction model, and post estimation tests, including linearity test, normality test, serial correlation tests, and heteroskedasticity test.

\section{DATA ANALYSIS AND DISCUSSION}

Table 4.1: Correlation Statistics

\begin{tabular}{|c|c|c|c|c|}
\hline & GDP & EXR & OILP & INVR \\
\hline GDP & 1.000000 & & & \\
\hline EXR & 0.288571 & 1.000000 & & \\
\hline OILP & 0.210025 & -0.032829 & 1.000000 & 0.732798 \\
\hline INVR & 0.192185 & -0.111970 & 0.732798 & 1.000000 \\
\hline
\end{tabular}

Source:Authors'computation (2020)

Estimates of correlation analysis in Table 4.1 above make noticeable the existence of a positive correlation between economic sustainability indicators - gross domestic product and other economic variables used in the study. Remarkably, the correlation coefficient stood at $0.288571,0.210025$, and 0.192185 for GDP and EXR, GDP and OILP, GDP and INVR, respectively, demonstrating that economic sustainability is the sensitive exchange rate, oil price, and investment rate. The correlation coefficient for other groups of variables reflected a negative relationship with a particular coefficient estimate of -0.032829 for EXR and OILP and 0.1119870 for EXR and INVR, thus showing that these variables move predominantly in a different direction.

Table 4.2: Abridged Result of Unit Root Test

\begin{tabular}{|c|c|c|c|c|c|c|c|}
\hline \multicolumn{4}{|c|}{ At Level } & \multicolumn{4}{c|}{ At First Difference } \\
\hline Variables & $\begin{array}{c}\text { ADF } \\
\text { Statistics }\end{array}$ & $\begin{array}{c}1 \% \text { critical } \\
\text { value }\end{array}$ & $\begin{array}{c}5 \% \text { critical } \\
\text { value }\end{array}$ & ADF Statistics & $\begin{array}{c}1 \% \\
\text { critical } \\
\text { value }\end{array}$ & $\begin{array}{c}5 \% \text { critical } \\
\text { value }\end{array}$ & $\begin{array}{c}\text { Order of } \\
\text { integration }\end{array}$ \\
\hline GDP & -4.415121 & -3.886751 & -3.052169 & -6.354540 & $-3.920350^{*}$ & -3.065585 & $\mathrm{I}(1)$ \\
\hline EXR & -5.621039 & -3.886751 & -3.052169 & -9.582539 & $-3.920350^{*}$ & -3.065585 & $\mathrm{I}(1)$ \\
\hline OILP & -1.854920 & -3.886751 & -3.052169 & -4.718551 & $-3.920350^{*}$ & -3.065585 & $\mathrm{I}(1)$ \\
\hline INVR & -1.825847 & -3.920350 & -3.065585 & -5.942639 & $-3.920350^{*}$ & -3.065585 & $\mathrm{I}(1)$ \\
\hline
\end{tabular}

Note: $*(* *)$ connote significance at $1 \%$ and $5 \%$ significant levels respectively

Source:Authors'computation (2020)

The result from the unit root test demonstrated in Table 4.2 describes Augmented Dickey-Fuller (ADF) statistics together with critical values tested at $1 \%$ and $5 \%$ significant levels. Discoveries from this estimation revealed that the study's proxies are not stationary level; this is premised on the reality that the ADF statistics of some variables are lower than the statistics at $1 \%$ and $5 \%$ critical value, respectively. Notwithstanding, every variable or proxy turned stationary at the first difference, suggesting that they are integrated in the same order. Based on the affirmation of the variables incorporated in the same order, it is essential to note an imbalanced association between variables in the short term, considering the confirmation of unit root. Although a change for a long-run equilibrium association of the variables, especially in the likely state of co-integration, exists, in the bid to ascertain this argument, Johansen co-integration test will be carried out in this study. 


\section{Co-integration Analysis}

Table 4.3: Johansen Co-integration Test Result

Series: GDP, EXR, OILP, INVR

\begin{tabular}{|c|c|c|c|c|}
\hline $\begin{array}{c}\text { Eigen } \\
\text { Value }\end{array}$ & $\begin{array}{c}\text { Trace } \\
\text { Statistics }\end{array}$ & $\begin{array}{c}5 \text { Percent } \\
\text { Critical } \\
\text { Value }\end{array}$ & Probability & $\begin{array}{c}\text { Hypothesized } \\
\text { No of } \\
\text { CE(s) }\end{array}$ \\
\hline 0.962091 & 98.46529 & 47.85613 & 0.0000 & None * \\
\hline 0.904612 & 46.10418 & 29.79707 & 0.0003 & At most $1 *$ \\
\hline 0.384183 & 8.507351 & 15.49471 & 0.4128 & At most 2 \\
\hline 0.045822 & 0.750473 & 3.841466 & 0.3863 & At most 3 \\
\hline
\end{tabular}

$*$ denotes rejection of the hypothesis at $1 \%$ significance level

Trace test indicates 2 co-integrating eqn(s) at the 0.05 level

Source: Authors' computation (2020)

Results shown in Table 4.3 reflect an abridged report of cointegration estimation carried out in the study to assess the long-run implication of the shock suffered by various economic indicators over a few quarters. Estimates of trace statistics revealed in the above table suggest the need to assess the long-run association of these proxies; hence, the cause for estimating co-integration regression.

Table 4.4: Co-integration Regression

Series: GDP, EXR, OILP, INVR

\begin{tabular}{|c|c|c|c|c|}
\hline Variables & Coefficient & Std. Error & t-statistics & Probability \\
\hline C & -15109803 & 32503547 & -0.464866 & 0.6492 \\
\hline EXR & 107753.7 & 87400.74 & 1.232869 & 0.0379 \\
\hline OILP & 94543.38 & 295836.7 & 0.319580 & 0.0540 \\
\hline INVR & 75.43319 & 196.1742 & 0.384521 & 0.0064 \\
\hline
\end{tabular}

R-square $=0.140582$, Adjusted R-square $=0.043580$

Source: Authors'computation (2020)

Co-integration regression estimates shown in Table 4.4 demonstrates that in the long run, the exchange rate exerts a significant positive impact on gross domestic product in Nigeria, with a coefficient estimate of

$107753.7(\mathrm{p}=0.0379<0.05)$. Again, results also revealed that oil price exerts a noticeable positive impact on gross domestic product in Nigeria with a ballpark estimate of 94543.38 $(\mathrm{p}=0.0540=0.05)$. Also indicated in the attained result is the significant positive impact of investment rate on the gross domestic product of Nigeria with a coefficient estimate of $75.43319(\mathrm{p}=0.0064<0.05)$. A further measure of the model's suitability revealed that R-square statistics stood at 0.043580 , suggesting that in the distant future, exchange rate, oil price, and investment rate will control the change in the gross domestic product at a moderate level, ceteris paribus; this suggests that the effect of COVID-19 on the economic sustainability of Nigeria, in the long run, will be mild or might be almost unnoticeable in the long run.
Table 4.5: Parsimonious Error Correction Model

Series: GDP, EXR, OILP, INVR

\begin{tabular}{|c|c|c|c|c|}
\hline Variable & Coefficient & Std. Error & t-Statistic & Prob.* \\
\hline $\mathrm{D}(\mathrm{GDP}(-2))$ & -0.892023 & 0.204218 & -4.367989 & 0.1433 \\
\hline $\mathrm{D}(\mathrm{GDP}(-3))$ & -0.273885 & 0.163645 & -1.673656 & 0.3429 \\
\hline $\mathrm{D}(\mathrm{EXR})$ & 349910.3 & 782418.3 & 0.447216 & 0.7323 \\
\hline $\mathrm{D}(\mathrm{EXR}(-1))$ & 3933339. & 1872190. & 2.100929 & 0.0282 \\
\hline $\mathrm{D}(\mathrm{EXR}(-2))$ & -6949116. & 1056828. & -6.575445 & 0.0961 \\
\hline $\mathrm{D}(\mathrm{OILP})$ & -628401.6 & 572593.5 & -1.097466 & 0.4704 \\
\hline $\mathrm{D}(\mathrm{OILP}(-1))$ & -510713.9 & 398472.4 & -1.281679 & 0.4218 \\
\hline $\mathrm{D}(\mathrm{OILP}(-2))$ & -953260.2 & 649716.2 & -1.467195 & 0.0380 \\
\hline $\mathrm{D}(\mathrm{INVR})$ & -36.12343 & 293.5806 & -0.123044 & 0.9221 \\
\hline $\mathrm{D}(\mathrm{INVR}(-1))$ & 2373.344 & 1142.415 & 2.077480 & 0.0285 \\
\hline $\mathrm{D}(\mathrm{INVR}(-2))$ & 3779.079 & 2009.622 & 1.880492 & 0.3111 \\
\hline $\mathrm{ECT} 01$ & -6.101914 & 3.052228 & -1.999167 & 0.2953 \\
\hline $\mathrm{C}$ & -31015591 & 14331579 & -2.164143 & 0.2756 \\
\hline
\end{tabular}

$\mathrm{R}$-square $=0.991145$, Adjusted R-square $=0.884887$, Durbin - Watson $=$ 2.138148

Source:Authors'computation (2020)

Estimates of parsimonious error correction model presented in Table 4.5 hold that in the short run, exchange rate exerts an insignificant negative impact on the gross domestic product with coefficient lagged estimate of -6949116 $(\mathrm{p}=0.0961<0.05)$, oil price exerts a significant adverse effect on the gross domestic product with a selected lag estimate of $953260.2(\mathrm{p}=0.0380<0.05)$.In contrast, the investment rate was determined to impact Nigeria's gross domestic product with a significantly positively lagged assessment of 2373.344 $(0.0285<0.05)$. The coefficient of one period lagged error correction term shown in the above table stood at -6.101914 with a probability value of 0.7768 , suggesting that about $6 \%$ of the unexpected short-run variations are rectified and incorporated into the dynamics noticed quarterly in the long run. Furthermore, R-square statistics of 0.884887 also revealed that in the short run, variation noticed in the gross domestic product can be jointly controlled by the exchange rate, oil price, and investment rate up to about $88 \%$. As evident in the massive and significant effect of COVID-19 on the stability and sustainability of the economy in the short run, the R-square obtained further describes the noticeable impact of the pandemic in the briefest term in Nigeria.

Table 4.5: Post Estimation Test

\begin{tabular}{|c|c|c|}
\hline \multicolumn{3}{|c|}{ Linearity Test } \\
\hline Variables & Values & Probability \\
\hline T-statistics & 0.173521 & 0.8649 \\
\hline F-statistic & 0.030110 & 0.8649 \\
\hline Likelihood Ratio & 0.041642 & 0.8383 \\
\hline
\end{tabular}




\begin{tabular}{|c|c|c|}
\hline \multicolumn{3}{|c|}{ Normality Test } \\
\hline Statistics & Values & Probability \\
\hline Jarque-Bera Stat & 72.77528 & 0.0000 \\
\hline \multicolumn{3}{|c|}{ Heteroskedasticity Test } \\
\hline Statistics & Values & Probability \\
\hline F-statistic & 0.026437 & 0.973940 \\
\hline
\end{tabular}

Source: Authors'computation (2020)

Ballpark figures of Ramsey linearity test presented in Table 4.5emphasises on three statistics such as T-statistics, Fstatistics, and likelihood ratio together with their respective probability values. T-statistics of $0.173521(\mathrm{p}=0.8649>0.05)$, F-statistics of $0.030110(\mathrm{p}=0.8649>0.05)$ and likelihood ratio of $0.041642(\mathrm{p}=0.8383>0.05)$ were reported in the above table; hence affirming the correctness in the parameters combined in the study's model.Jarque-Bera statistics alongside probability values revealed in Table 4.5 stood at $72.77528(\mathrm{p}=0.0000<0.05)$; given the positive estimate and significant level, it justifies the normal distribution of data sampled by the study. Lastly, Table 4.5 also holds F-statistics and probability values of $0.026437(\mathrm{p}=0.9739>0.05)$ for the heteroskedasticity test and premised on the reported Fstatistics. It is confirmed that no issue of heteroskedasticity in the error term of the study's model exists.

\subsection{Discussion}

Most predictable and effectual estimation indicates that in the long run, the exchange rate exerts a noticeable positive impact on the gross domestic product with an identified ballpark estimate of $107753.7(p=0.0379<0.05)$. This result suggests that an increase in the exchange rate will culminate into about 107,753.7 million naira increase in the gross domestic product of Nigeria. Also, results attained further revealed that in the long run, the oil price will impact positively and significantly on the gross domestic product with a coefficient estimate of $94543.38(\mathrm{p}=0.0540=0.05)$; hence pointing that a shoot up in oil price will occasion an increase in gross domestic products to the tune of $94,543.38$ million nairas. It was also discovered that the investment rate exerts a significant positive impact on the gross domestic products of Nigeria. This implies that a consistent increase in the investment rate will shoot up Nigeria's gross domestic product by about 75.43319 million nairas.

Further estimation revealed that in the short run, the exchange rate impacts negatively on the gross domestic product with a ballpark estimate of $-6949116(\mathrm{p}=0.0961<0.05)$. This result affirms that a steady fall in the exchange rate will trigger an increase in the gross domestic product of Nigeria by about 6949116 million nairas. Results also revealed that oil price exerts a significant adverse effect on gross domestic products with a coefficient estimate of about -953260.2 $(p=0.0380<0.05)$; this indicates that the fall in oil price will fall in the short run occasion a significant increase in gross domestic product. Finally, the investment rate was noticed from the result to positively affect gross domestic product with a coefficient estimate of $2373.344(0.0285<0.05)$. This connotes that an increase in investment rate will cause a significant increase in gross domestic product with a particular estimated value of about 2373.344 million nairas.

\section{CONCLUSION AND RECOMMENDATIONS}

This study confirms that exchange rate, oil price, and investment rate, in the long run, exert a noticeable positive impact on economic sustainability captured with gross domestic product. It implies that regardless of the financial condition of the country as well as shocks suffered by both the micro and macroeconomic environment, in the long run, a usually stable economy will recover from the economic losses it suffered and maintain its stability. However, discoveries reached in the study point that the long-term stability in these financial proxies will culminate into healthy, sustainable economic growth. More importantly, in the short run and as experienced in Nigeria after the advent of coronavirus, the exchange rate and oil price shock negatively impacted economic sustainability while the investment rate reduced significantly. This reflects that improper management and coordination have been the case in Nigeria's economy. As findings reached in this study revealed that moderate oil price and, in the worst case, fall in oil price and exchange rate may still command stability and sustainability in economic growth. Also, the investment rate captured with domestic savings suffered a massive decline in recent times. Still, it maintained a positive effect on financial sustainability, a pointer that although unfavorable economic situations like the pandemic are bound to occur, the sustainability and growth of the economy can be attained. Hence, it is evident that the pandemic possesses the strength to destroy the economy of Nigeria, particularly in the short run, as observed in other countries. However, the recommendations listed below will bring adequate control and ultimately attract stability in the economic growth of Nigeria. Based on this premise, it is expedient that:

i. The Central Bank of Nigeria should maintain the stability of the exchange rate through effective permeation and transformation of external reserves.

ii. The government of Nigeria should switch the economy from a single or mono-economy and save the country from a massive economic crash that will follow any utter decline in oil price.

iii. The Central Bank of Nigeria should further improve financial inclusion; this will undoubtedly enhance savings behavior, increase access to affordable funds, and ultimately encourage investment.

\section{REFERENCES}

[1] Acikgoz, O. \&Gunay, A. (2020). The early impact of the Covid-19 pandemic on the global and Turkish economy.Turkish Journal of Medical Sciences, 50(1), 520-526.

[2] Adeyeye, P.O., Fapetu, O., Aluko, O.A., \&Migiro, S.O. (2015). Does supply-leading hypothesis hold in a developing economy? A Nigerian focus.Procedia Economics and Finance, 30, 30-37. 
[3] Adeyinka, O., Fadila, K.U., Bodam, F., Dansofo, A.T. \&Adetunji, D.A. (2020). Coronavirus facts and control: What multiplier effects for the Nigerian Economy?International Virtual Conference on Social Science, 1-7.

[4] Ahmad, T., Haroon, Baig, M. \&Hiu, J. (2020). Coronavirus disease 2019 (COVID-19),pandemic and economic impact.Pak $J$ Med Sci.36(4), 1-7.

[5] Akpoveta, O.A\&Edheku, O.J. (2020).COVID-19 pandemic: Nigeria's economic and business disruptions. International Scholar Journal of Arts and Social Science Research, 2(4), 13-31.

[6] Barrett, C., Bisset, K., Leidig, J., Marathe, A. \&Marathe, M. (2011).Economic and social impact of influenza mitigation strategies by demographic class.Epidemics, 3(1), 19-31.

[7] Bernburg, J. G. (2016). Economic crisis and mass protest: The pots and pans revolution in Iceland. Routledge. Abingdon, United Kingdom.

[8] China CDC.(2020). 2019 Novel coronavirus, Wuhan, China.Retrieved from https://www.cdc.gov / Coronavirus/2019nCoV/summary.html.

[9] European Central Bank. (2020). Press release: Pandemic Emergency Purchase Programme (PEPP). Frankfurt, Germany.

[10] Francois, J., \&Woerz, J. (2009). The big drop,trade and the Great Recession: The Great trade collapse: Causes, consequences, and prospects. VoxEU.org.

[11] Giugni, M., \& Grasso, M. T. (2016).Austerity and protest: Popular contention in times of economic crisis. Routledge. Abingdon, United Kingdom.

[12] Hart, P., \&Tindall, K. (2009).From market correction to global catastrophe: Framing the economic downturn. A Publication of TheAustrialianNattional University, Camberra, Austrailia.

[13] International Monetary Fund.(2020). Statement by the International Monetary and Financial Committee on the coronavirus. Washington, USA.

[14] Jones, C. (2016). The credit crunch: Short-term UK housing market correction or long-term tipping point? International Journal of Housing Policy, 16(1), 70-90.

[15] Jones, O.B. (2018). World Development Report: Pandemic risk. Washington, USA: World Bank Publication.

[16] Joshi, A., Bhaskar, P. \& Gupta, P.K. (2020). Indian economy amidCOVID-19 lockdown: A perspective. $J$ Pure ApplMicrobiol,14(1), 957-961.

[17] Karimo, T.M. \& Oliver, E.O. (2017). Financial deepening and economic growth nexus in Nigeria: Supply-leading or demandfollowing?Economies, 5(4), 1-18.

[18] Keogh-Brown, M.R. \&Smith, R.D. (2008). The economic impact of SARS: How does the reality match the predictions? Health Policy, 88(1), 110-120.

[19] Lagravinese, R. (2015). Economic crisis and rising gaps NorthSouth: Evidence from the Italian regions. Cambridge Journal of Regions, Economy and Society, 8(2), 331-342.
[20] Lee, J,W. \&McKibben, W.J (2004). Globalization and disease: The case of SARS. Cambridge, MA, USA: MIT Press.

[21] Nwugbe, A. \&Ogbuagu, M. (2014).Global financial crisis and the Nigerianeconomy.Global Journal of Management and Business Research: Economics and Commerce. 14(4), 25-30.

[22] Ohwofasa, B.O., \&Aiyedogbon, J.O. (2013). Financial deepening and economic growth in Nigeria: An empirical investigation. Journal of Economics and Development Studies, 1(1), 22-42.

[23] Organisation for Economic Co-operation and Development. (2020). OECD interim economic assessment of coronavirus: The world economy at risk. Paris, France.

[24] Ozigbu, J.C. (2018). Evaluating the supply-leading hypothesis in sub-Saharan Africa: Lesson from the Nigerian manufacturing sector.Journal of Innovation \& Development.7(1), 323-332.

[25] Ozili, P. \&Arun, T. (2020). Spillover of COVID-19: Impact on the global economy. Munich Personal RePEc Archive. Paper No. 99317.

[26] Ozili, P. (2020). COVID-19 pandemic and economic crisis: The Nigerian experience and structural causes. Journal of Social Science, 1(1), 1-20.

[27] Premium Times. (2020). Coronavirus: Nigeria cuts oil benchmark to $\$ 30$, slashes capital budget by $20 \%$. 18 March 2020 . Retrieved from https://www.premiumtimesng.com/coronavirus/382605coronavirus-nigeria-cuts-oilbenchmark-to-30-slashes-capitalbudget-by-20.html

[28] Rabiu, M., Musa, K.S., Isah, A.A. \&Adamu, S. (2020). Analysis of the impact of coronavirus outbreak on the Nigerian economy.American Journal of Environmental and Resource Economics,5(2): 39-43

[29] Rahman, S. \&Bahar, T. (2020).COVID-19: The new threat.International Journal of Infection, 7(1), 21-34.

[30] Reuters. (2020). Coronavirus very likely of animal origin, no sign of laboratory manipulation: WHO. April 21, 2020/11:26am

[31] Robinson, J.C. (1952). The generalisation of the general theory in the rate of interest and other essays. London: Macmillan Press.

[32] The General Administration of Customs of the People's Republic of China. (2020). Monthly bulletin: Summary of imports and exports (in USD). Beijing, China.

[33] The US Department of Labour. (2020). News release: The employment situation. March 2020. Washington, USA.

[34] The US Department of Labour. (2020). News release: Unemployment insurance weekly claims. Washington, USA.

[35] United Nations Conference on Trade and Development. (2020). Thecoronavirus shock: A story of another Gglobalcrisis foretold and what policymakersshould be doing about it. Geneva, Switzerland.

[36] World Bank. (2020). Press Release No: 2020/138/EXC. Washington, USA.

[37] World Health Organisation. (2020). Coronavirus disease (COVID2019): Situation report-78. Geneva, Switzerland. 